\title{
Long-term results of uncemented allograft prosthesis composite reconstruction for the tumor in proximal femur: a minimum follow-up of sixty-five months
}

\author{
Cai Liư ${ }^{\dagger}$ Li Min ${ }^{\dagger}$, Yong Zhou, Yi Luo, Fan Tang, Minxun Lu, Hong Duan, Wenli Zhang, Xinzhu Yu and \\ Chongqi Tu* (D)
}

\begin{abstract}
Background: Uncemented allograft prosthesis composite (APC) has been applied for tumorous bone defect reconstruction in the proximal femur. However, the long-term results are rarely reported. This study aimed to evaluate long-term outcomes of uncemented APC.

Methods: Eighteen patients who received uncemented APC reconstruction in the proximal femur after tumor resections were retrospectively reviewed.

Results: The average resection length was $110 \mathrm{~mm}$ (80-154) and the average follow-up was 106.7 months (65-141). Bone union achieved in all patients with an average duration of 7.6 months (5-10). The average HHS, MSTS score and gluteus medius strength at one-year follow-up were 88.0 (80-94), 25.2 (22-28) and 4 (3-5), respectively. While at the last follow-up, the HHS, MSTS score and gluteus medius strength were 83.0 (48-100), 24.0 (10-30) and 4 (25), respectively. Five intraoperative fractures were fixed with cerclage wires. Two postoperative periprosthetic and prosthetic fractures received a revision. Three local recurrent patients received a secondary surgery. One of these three lung metastatic patients underwent lung metastatic tumor resection. Another two patients were diagnosed with both bone and lung metastases, only one of them underwent amputation. Two greater trochanteric fractures received no treatment. There were10 severe, 3 moderate and 5 mild allograft resorptions without treatment.
\end{abstract}

Conclusion: Uncemented APC is a reliable reconstruction for neoplastic bone defect of the proximal femur, especially for the young patient who expected long-life expectancy and good function. Though allograft resorption and trochanteric fracture are the common complications, they seem no effect on the function.

Keywords: Uncemented, Allograft-prosthesis composite, Proximal femur, Tumor

\section{Background}

The proximal femur is one of the most frequent sites for aggressive benign tumors and primary malignancies [1]. Functional reconstructions for oncological bone defects

\footnotetext{
* Correspondence: tuchongqibone@outlook.com

${ }^{+}$Cai Liu and Li Min contributed equally to this work. Department of Orthopedic Surgery, West China Hospital of Sichuan University, Guoxue Road 37\#, Chengdu 610041, China
}

in the proximal femur remain challenging. Since the 1960s, reconstruction with osteoarticular allograft has been used [2,3]. However, the limitation has been reported as the high rate (nearly $70 \%$ ) of complications, such as fracture, infection, degeneration and disintegration $[4,5]$. At present, reconstruction with endoprosthesis, known as the gold standard, still has its shortcomings, including lower abductor muscle strength,

(c) The Author(s). 2021 Open Access This article is licensed under a Creative Commons Attribution 4.0 International License, which permits use, sharing, adaptation, distribution and reproduction in any medium or format, as long as you give appropriate credit to the original author(s) and the source, provide a link to the Creative Commons licence, and indicate if changes were made. The images or other third party material in this article are included in the article's Creative Commons licence, unless indicated otherwise in a credit line to the material. If material is not included in the article's Creative Commons licence and your intended use is not permitted by statutory regulation or exceeds the permitted use, you will need to obtain permission directly from the copyright holder. To view a copy of this licence, visit http://creativecommons.org/licenses/by/4.0/ The Creative Commons Public Domain Dedication waiver (http://creativecommons.org/publicdomain/zero/1.0/) applies to the data made available in this article, unless otherwise stated in a credit line to the data. 
impaired function, Trendelenburg gait, loosening, structural failure and dislocation [6-9]. Meanwhile, with the development of neoadjuvant chemotherapy, radiotherapy, immunotherapy and targeted therapy, more and more patients with bone malignancies tend to have a better prognosis with longer life expectancy [10]. Hence, it's of great significance to preserve favorable limb function and increase implant survival after reconstruction.

Allograft prosthesis composite (APC), a hybrid of endoprosthesis and allograft, holds the merits of these two methods with fewer disadvantages [11]. Since the 1980 s, it has been used for the reconstruction of neoplastic bone defects and revision hip arthroplasty (RHA), especially when the circumferential femoral bone defects are greater than $3 \mathrm{~cm}$ in length [12-14]. Compared with endoprosthesis, APC reconstruction seems biological based on the advantages of improving gait, restoring bone stock, biological reconstruction of the abductors, providing weight-bearing and reducing stress shielding after bone union $[1,15,16]$. Nowadays, the APC technique can be divided into cemented, uncemented or partial cemented. However, the cemented or partial cemented APC hold a high rate of nonunion in previous studies, up to $23 \%$ [1, 14, 17-21]. Additionally, revision of cemented or partial cemented APC needs to remove the allograft, which makes the advantage of restoring bone stock no longer exist [14, 21, 22].

Since 2007, uncemented APC has been used for the reconstruction of tumorous proximal femoral defect in our institute [23]. The short-term follow-up was promising [23]. After a long-term follow-up of these patients, some new information is worth sharing. Thus, the objectives of our study were to: 1) present the long-term clinical, oncological outcomes and complications of uncemented APC reconstruction; 2) how to manage the complications.

\section{Methods}

From 2007 to 2014, we have performed uncemented APC reconstruction for 25 cases with a malignant or aggressive benign bone tumor in the proximal femur. Indications have been described in our previous study [20, 23]. In this study, exclusion criteria were: 1) metastasis of the proximal femur; 2) the malignant tumor invaded the hip joint, even the acetabulum; 3) the follow-up less than 5 years. Therefore, 7 patients were excluded, including 1 infection, 1 death and 5 lost to follow-up. In all, 18 patients (7 male and 11 female, sex ratio: $0.6,18$ hips) were analyzed in this study. The average age was 30.8 years $(17-52)$. The pathological diagnoses were 2 chondrosarcoma (CS), 1 malignant fibrous histiocytoma (MFH), 8 giant cell tumor of bone (GCTB), 3 osteoblastoma (OB), 1 osteoblastic osteosarcoma (OBOS), 2 osteosarcoma (OS) and 1 fibroblastic osteosarcoma (FBOS). Eleven benign tumors were grade 3 according to the Enneking stage [24]. For malignant tumors, there were 6 grade IIB and 1 grade IIA according to the American Joint Committee on Cancer (AJCC) Staging system [25]. Seven patients had operations before, including 4 GCTB, 1 FBOS and 2 OB. Eight patients presented with pathological fractures, including 5 GCTB, 2 OS and 1 CS (Table 1). Five patients had neoadjuvant chemotherapy.

\section{Preoperative assessments}

The examinations of $100 \%$ magnified X-ray (Whole femur and pelvic), computed tomography (CT) scan, magnetic resonance imaging (MRI) and single-photon emission computed tomography (SPECT) were necessary. According to these results, we identified the resection length, the exact boundary of the tumor, the narrowest diameter of the medullary canal and cortex thickness of the distal femur, which were beneficial for choosing the optimum allograft. All diagnoses were confirmed by biopsies or ex-surgeries. Neoadjuvant chemotherapies were routinely taken for patients with malignant bone tumors. All the patients were informed of the use of allografts. The allografts were obtained

\section{Table 1 Patients characteristics ${ }^{a}$}

\begin{tabular}{ll}
\hline Data & \\
\hline Age (years) & $30.8(17$ to 52) \\
Gender & $7(38.9 \%)$ \\
Male & $11(61.1 \%)$ \\
Female & \\
Diagnosis & $2(11.1 \%)$ \\
Chondrosarcoma & $1(5.6 \%)$ \\
Malignant fibrous histiocytoma & $8(44.4 \%)$ \\
Giant cell tumor of bone & $3(16.7 \%)$ \\
Osteoblastoma & $1(5.6 \%)$ \\
Osteoblastic osteosarcoma & $2(11.1 \%)$ \\
Osteosarcoma & $1(5.6 \%)$ \\
Fibroblastic osteosarcoma & $18(100 \%)$ \\
Primary & $7(38.9 \%)$ \\
Recurrence before surgery & \\
Pathological fracture before surgery & $8(44.4 \%)$ \\
Yes & $10(55.6 \%)$ \\
No & $5(27.8 \%)$ \\
Resection length (mm) & $110(80$ to 154$)$ \\
Acetabular type & \\
DePuy metal socket & $17(94.4 \%)$ \\
Cage & $1(5.6 \%)$ \\
Vnion time of the host and allograft (months) & $7.6 \mathrm{months}(5$ to 10$)$ \\
\hline
\end{tabular}

${ }^{a}$ Values are numbers of patients (percentages) unless otherwise indicated 
from the bone bank of Sichuan province, People's Republic of China.

\section{Surgical techniques}

All the operations were performed with a lateral approach by the senior surgeon (Chongqi Tu) in West China Hospital. The previous biopsy tracks were removed en bloc. The surgical procedure included 3 major steps: allograft preparing, tumor resection and reconstruction, which had been described thoroughly in our previous study [23].

The allograft preparation was done on another sterile operation table, including 3 procedures: First, the allograft was soaked with povidone-iodine solution for 30 mins and pulsatile lavaged with a large amount of saline solution and degreased with medical alcohol; Second, the bone was resected the exact length according to the measurements before the surgery through the imageology data and during the operation; Finally, the greater and lesser trochanters were prepared by removal of the allograft tissue and drilled for the reconstruction of the soft tissue.

The tumor resection was performed on the operation table. The abductor muscles (Mainly gluteus medius) and iliopsoas were saved as much as possible and marked respectively. To achieve a wide, safe boundary, an en bloc resection with at least $2 \mathrm{~cm}$ was performed for aggressive benign or bordering tumors and a $5 \mathrm{~cm}$ for primary malignant tumors. No greater trochanteric osteotomy was performed in our series. Before osteotomy, the precise resection length was measured again, which was measured from the tip of the greater trochanter. If possible, a $10-15 \mathrm{~mm}$ normal periosteal cuff was preserved. Then, the osteotomy was carried out horizontally and the distal femoral medullary tissue was sent for frozen biopsy to make sure the en bloc resection.

Reconstruction proceeded as follows: Initially, osteotomy of the neck was performed and the medullary canal was reamed to fit the prosthesis. A propriate length of prosthesis was selected to meet the ratio of prosthetic length in host bone to in the allograft was close to (11.5):1. After a trial fitting, the prosthesis was fixed into the allograft bone by press-fit. Then, a second trial was performed and the host bone was reamed to fit the composite prosthesis. After that, the allograft composite was inserted into the host bone by pressure, similar to an endoprosthesis. To make sure the prosthetic anteversion was around $15^{\circ}$, the knee was flexed at an angle of around $90^{\circ}$. Then, the allograft composite would be gradually inserted into the host with an angle around $105^{\circ}$ formed by comparing the tibial axis with the prosthetic femoral neck axis. Once the allograft and host bone contacted well, the junction was covered with granular allogenous spongy bone and the periosteal cuff.
Finally, the important muscles were reconstructed. The gluteus medius and gluteus minimus were fixed together to the greater trochanter in 13 patients, while the rest patients with the gluteus medius insertion preserved, sutured onto the allograft greater trochanter, which had been described in our previous studies [20, 23]. Meanwhile, the iliopsoas was sutured to the lesser trochanter of the allograft. The gluteus maximus tendon was sutured to the tissues surrounded instead of its anatomic place. All patients had the vastus lateralis, the gluteus medius and the fascia lata sutured together.

\section{Postoperative management}

The prophylactic intravenous antibiotics were used for 1-2 days as usual. An abduction T-shaped pillow and anti-rotation shoes were used to ensure the lower extremity in the abduction-neutral position without rotation of the affected limb. The isometric exercises of quadriceps femoris, moves of the ankle, raise of buttock, the practice of cough and deep breath were recommended immediately after the operation and last for 4 weeks in bed. Antithrombotic drugs were used in this period until partial weight-bearing was admitted. Then, 8 weeks later, full weight-bearing was allowed.

\section{Clinical and radiographic assessments}

All patients were followed up in the outpatient clinic monthly in the first 6 months, after that, every 3 months for the first 2 years and then annually. Harris Hip Score (HHS: for which a score of $<70$ is poor, $70-79$ is fair, $80-89$ is good and 90-100 is excellent) and Musculoskeletal Tumor Society (MSTS) score were used for the evaluation of the functional outcomes. To assess the impact of postoperative complications on function, the HHS and MSTS score of the pre-operation, one-year follow-up and last follow-up were recorded, respectively $[26,27]$. The abductors' strength was scored by the strength of the gluteus medius.

Whole femoral and 100\% magnified AP pelvis X-rays were performed at 1, 3, 6, 9 and 12 months after surgery, then, annually. In the later follow-up, TomosynthesisShimadzu metal artifact reduction technology (T-SMAR $\mathrm{T}$ ) or CT would be taken if necessary, especially when the follow-up was over 5 years. Bone union at the host and allograft junction was defined as blurring showed in the radiography, usually combined with bridging trabeculae at the junction without radiolucent lines. Nonunion was confirmed if no further progress at the conjunction was observed for more than 1 year [23].

The allograft and the host were divided into 7 zones similar to those of Gruen [28]. The resorption in these zones was recorded. The severity of the resorption was graded as mild, moderate and severe [29]. 


\section{Statistical analysis}

Continuous variables were expressed as mean (Range) and compared using the Wilcoxon Signed Ranks Test and Mann-Whitney Test. $P<0.05$ was considered to be significant. Statistical analysis was performed with SPSS Advanced Statistics 23.0 software (IBM, Armonk, NY).

\section{Results}

The average resection length was $110 \mathrm{~mm}(80-154)$ and the average follow-up was 106.7 months (65-141). Bone union at the allograft-host junction achieved in all patients on an average of 7.6 months (5-10) without a delayed union.

The HHS was significantly improved from 41.0 (20$58)$ pre-operation to $88.0(80-94)$ at one-year follow-up $(p<0.01)$ while $83.0(52-100)$ at the last follow-up $(p<$ $0.01)$. The MSTS score was improved from 9.2 (4-15) pre-operation to $25.2(22-28)$ at one-year follow-up ( $<<$ $0.01)$ while $24.0(10-30)$ at the last follow-up ( $<<0.01)$. According to the HHS, at one-year follow-up, 9 (50\%) patients got excellent and 9 (50\%) got good. However, 11 (61.1\%) patients got excellent, 2 (11.1\%) achieved good, 1 (5.6\%) fair and $4(22.2 \%)$ poor at the last followup. The average strength of the gluteus medius was 4 $(3-5)$ at one-year follow-up while $4(2-5)$ at the last follow-up $(p=0.700)$ (Table 2).

There were 5 intraoperative fractures, 2 postoperative periprosthetic and prosthetic fractures (PPPFs), and 2 trochanteric fractures. All intraoperative fractures were longitudinal, no more than $2 \mathrm{~cm}$ in length, stable and incomplete crack fractures, which were fixed with cerclage wires. One patient had a recurrent in the area of the allograft (Patient No.16). The follow-up X-ray of the rest 4 showed the union of the allograft-host junction, no subsidence of the prosthesis and no obvious lucent line between the prosthesis and allograft. Two PPPFs received a revision. One (Patient No.12) occurred at 10 $\mathrm{mm}$ above the allograft-host junction line 105 months postoperatively. A longer stem was used without removing the allograft. The other one (Patient No.15) with soft tissue recurrence, occurred at $37 \mathrm{~mm}$ above the allograft-host junction line 75 months postoperatively. The revision with endoprosthesis and recurrent tumor resection was carried out (Table 2). Two patients who had a greater trochanteric fracture 6 months postoperation received no treatment (Fig. 1).

Seven severe, 6 moderate and 3 mild resorptions were identified at one-year follow-up. At the last follow-up, there were 10 severe, 3 moderate and 5 mild resorptions. All involved in Gruen 1, 2 and 7 zone (Fig. 2). No treatment was performed.

Local recurrence (LR) developed in 3 patients. One patient (Patient No. 9) underwent a hemipelvectomy after several operations as the LR invaded the ipsilateral pelvic, and metastases in the lung and distal femur. One (Patient No.16) received the resection of the greater trochanteric for LR 71 months after the last operation. The last one (Patient No.15) has been mentioned above. Three patients developed lung metastasis. One (Patient No.13) received the metastasis removal 1 year postoperation. One (Patient No.17) was observed metastases in the ipsilateral pelvic and lung 9 months postoperation, having no treatment. The last one (Patient No. 9) has been mentioned above.

\section{Discussion}

Up to now, uncemented APC reconstruction for proximal femoral defect has only been reported with minor sample and short-term follow-up (Table 3). In our series, the clinical outcomes were updated with longer followup and enlarged samples based on our previous study regarding uncemented APC [23].

Previously, the average MSTS score of APCs reported in literatures ranged from 58.3 to $92.0 \%$, while the average HHS from 67.6 to $90.3[1,11,13,15,18,20,21,23$, $29,30,32]$. Favorable functional outcomes were demonstrated in our study. The average MSTS score and HHS were $80 \%(33.3-100 \%)$ and $83(48-100)$ respectively, which were comparable with other studies $[1,13,31]$. Although the MSTS score and HHS at the last follow-up decreased, no statistical significance was found when compared with that at one-year follow-up $(P=0.7$ and $P=0.74$ ). In our opinion, effective reconstruction of the abductors' attachment, especially the gluteus medius, is the key factor for the good function [15, 30, 33].

The failure rate for APC ranged from 10 to $50 \%$ [9]. The aseptic loosening, structure failure, infection and local recurrence contribute to the major causes for revisions [9]. In our study, the fracture was the most frequent complication including 5 intraoperative periprosthetic crack fractures, 2 PPPFs and 2 trochanteric fractures. This might have a great relationship with the fixation way of the prosthesis in the bone. Compared to cemented APC, the uncemented reconstruction was more skillful because the allograft and host bone medullary canal had to be reamed appropriately to avoid the early stem loosening and the periprosthetic fracture. Our intraoperative crack fractures were fixed with cerclage wires, the axial and torsional stabilities should be ensured, otherwise, plate fixation should be used. For comminuted fractures, a new allograft or extra plate fixation would be used if the stability was not achieved with cerclage wires [34]. Additionally, biomechanical test showed the fixation was stable enough even the longitudinal femoral crack fracture extended $4 \mathrm{~cm}$ distal to the lesser trochanter, compared with cable, or, a combination of cable and plate [35]. This secure fixation makes extra rehabilitation programs unnecessary. Two transverse PPPFs occurred $10 \mathrm{~mm}$ and $37 \mathrm{~mm}$ above the 
Table 2 Demographic characters and outcomes of 18 patients

\begin{tabular}{|c|c|c|c|c|c|c|c|c|c|c|c|c|c|c|}
\hline $\mathbf{P}$ & $\begin{array}{l}\text { A/ } \\
\text { G }\end{array}$ & Diag & $\begin{array}{l}\mathrm{St}(\mathrm{E} / \\
\mathrm{A})\end{array}$ & $\begin{array}{l}\mathrm{RL} \\
(\mathrm{mm})\end{array}$ & $\begin{array}{l}\text { Follow- } \\
\text { up } \\
\text { (months) }\end{array}$ & $\begin{array}{l}\text { HHS } \\
\text { (Pre) }\end{array}$ & HHS1 & HHS2 & $\begin{array}{l}\text { MSTS } \\
\text { (Pre) }\end{array}$ & MSTS1 & MSTS2 & SGM & Complications & Treatment \\
\hline 1 & $\begin{array}{l}\text { 20/ } \\
\mathrm{F}\end{array}$ & CS & $\begin{array}{l}\| B / \\
\| B\end{array}$ & 146 & 141 & 47 & 90 & 82 & 10 & 26 & 24 & 3 & Resorption (Gruen1.2.7) & - \\
\hline 2 & $\begin{array}{l}35 / \\
F\end{array}$ & MFH & $\begin{array}{l}\| A / \\
\| B\end{array}$ & 146 & 135 & 43 & 86 & 93 & 9 & 24 & 27 & 5 & Resorption (Gruen 1.7) & - \\
\hline 3 & $\begin{array}{l}31 / \\
F\end{array}$ & GCTB & $3 /-$ & 86 & 134 & 54 & 90 & 90 & 14 & 26 & 26 & 4 & Resorption (Gruen1.7) & - \\
\hline 4 & $\begin{array}{l}23 / \\
M\end{array}$ & $\mathrm{OB}$ & $3 /-$ & 97 & 134 & 58 & 80 & 88 & 15 & 23 & 25 & 4 & Resorption (Gruen1.7), IHF & - \\
\hline 5 & $\begin{array}{l}39 / \\
F\end{array}$ & GCTB & $3 /-$ & 80 & 126 & 47 & 85 & 95 & 10 & 24 & 27 & 5 & Resorption (Gruen1.7) & Cerclage wires \\
\hline 6 & $\begin{array}{l}25 / \\
F\end{array}$ & GCTB & $3 /-$ & 82 & 122 & 30 & 94 & 92 & 6 & 28 & 27 & 5 & Resorption (Gruen1.7) & - \\
\hline 7 & $\begin{array}{l}17 / \\
F\end{array}$ & $\mathrm{OB}$ & $3 /-$ & 94 & 122 & 54 & 88 & 94 & 14 & 25 & 28 & 5 & Resorption (Gruen1.7) & - \\
\hline 8 & $\begin{array}{l}47 / \\
M\end{array}$ & OBOS & $\begin{array}{l}\| A / \\
\| A\end{array}$ & 100 & 112 & 55 & 80 & 94 & 14 & 23 & 28 & 5 & Resorption (Gruen 1.7), IAF & Cerclage wires \\
\hline 9 & $\begin{array}{l}17 / \\
F\end{array}$ & $\mathrm{OB}$ & $3 /-$ & 131 & 110 & 54 & 94 & 53 & 14 & 28 & 13 & 2 & $\begin{array}{l}\text { Resorption (Gruen 1.2.7), LR, GTF } \\
\text { (P), metastasis of distal femur } \\
\text { and lung }\end{array}$ & Hemipelvectomy \\
\hline 10 & $\begin{array}{l}45 / \\
M\end{array}$ & OS & $\begin{array}{l}\| B / \\
\| B\end{array}$ & 127 & 107 & 20 & 88 & 100 & 4 & 25 & 30 & 5 & Resorption (Gruen 1.2.7), IHF & Cerclage wires \\
\hline 11 & $\begin{array}{l}52 / \\
\mathrm{F}\end{array}$ & CS & $\begin{array}{l}\| B / \\
\| B\end{array}$ & 123 & 107 & 20 & 80 & 91 & 4 & 23 & 26 & 4 & Resorption (Gruen 1.7) & - \\
\hline 12 & $\begin{array}{l}40 / \\
F\end{array}$ & GCTB & $3 /-$ & 93 & 105 & 30 & 90 & 92 & 6 & 26 & 27 & 4 & Resorption (Gruen 1.7), SF (P) & $\begin{array}{l}\text { Change the } \\
\text { stem }\end{array}$ \\
\hline 13 & $\begin{array}{l}17 / \\
M\end{array}$ & OS & $\begin{array}{l}\| B / \\
\| B\end{array}$ & 130 & 96 & 20 & 90 & 100 & 5 & 26 & 30 & 5 & $\begin{array}{l}\text { Resorption (Gruen 1.2.7), GTF (P), } \\
\text { metastasis of lung }\end{array}$ & $\begin{array}{l}\text { Metastasis } \\
\text { resection }\end{array}$ \\
\hline 14 & $\begin{array}{l}25 / \\
M\end{array}$ & GCTB & $3 /-$ & 80 & 88 & 30 & 92 & 94 & 6 & 27 & 28 & 4 & Resorption (Gruen1.7) & - \\
\hline 15 & $\begin{array}{l}33 / \\
M\end{array}$ & GCTB & $3 /-$ & 135 & 75 & 42 & 92 & 52 & 8 & 27 & 16 & 2 & Resorption (Gruen1.2.7), SF (P), LR & $\begin{array}{l}\text { Endoprosthesis, } \\
\text { recurrence } \\
\text { resection }\end{array}$ \\
\hline 16 & $\begin{array}{l}43 / \\
M\end{array}$ & GCTB & $3 /-$ & 98 & 71 & 32 & 86 & 65 & 6 & 24 & 19 & 3 & Resorption (Gruen 1.7), IAF, LR & $\begin{array}{l}\text { Cerclage wires, } \\
\text { recurrence } \\
\text { resection }\end{array}$ \\
\hline 17 & $\begin{array}{l}27 / \\
F\end{array}$ & GCTB & $3 /-$ & 83 & 70 & 47 & 80 & 48 & 10 & 22 & 10 & 4 & $\begin{array}{l}\text { Resorption (Gruen1.7), IAF, } \\
\text { metastasis of ipsilateral pelvic } \\
\text { and lung }\end{array}$ & Cerclage wires \\
\hline 18 & $\begin{array}{l}\text { 24/ } \\
F\end{array}$ & FBOS & $\begin{array}{l}\| A / \\
\| B\end{array}$ & 154 & 65 & 48 & 90 & 71 & 10 & 26 & 21 & 2 & Resorption (Gruen1.7) & - \\
\hline
\end{tabular}

Abbreviations: $P$ Patient number, A/G Age(years)/gender, $F$ Female, $M$ Male, Diag Diagnosis, CS Chondrosarcoma, MFH Malignant Fibrous Histiocytoma, GCTB Giant Cell Tumor of Bone, OB Osteoblastoma, OBOS Osteoblastic Osteosarcoma, FBOS Fibroblastic Osteosarcoma, St(E/A) Ttage(Enneking/AJCC), Pa Pathological fracture, Re Recurrence, RL Resection length, HHS Harris Hip Score, Pre Pre-operation, HHS1 HHS(One-year Follow-up), HHS2 HHS(One-year Follow-up), MSTS Musculoskeletal Tumor Society, MSTS1 MSTS (One-year follow-up), MSTS2 MSTS (Last Follow-up), SGM Strength of gluteus medius, IHF Intra-operative host fracture, GTF Greater Trochanteric Fracture, IAF Intra-operative allograft fracture, LR Local recurrence, SF Stem fracture, $P$ Post-operation

allograft-host junction line respectively due to powerful trauma, which indirectly verified the bone union at the allograft-host junction. The revision standard depends on the quality of the allograft. If the quality of the allograft is poor, endoprosthesis revision should be appropriate, or else, allograft should be preserved. In other literature, seven (18.4\%) periprosthetic fractures have been reported when using APC with short cemented stem and compressing plate [18]. Therefore, the long enough stem fixation demonstrates better load-sharing. And, the ratio of prosthetic length in host and allograft bone is recommended close to (1-1.5):1. In our study, two patients have been observed the trochanteric fracture with excellent and asymptomatic function during follow-up. The reason may be related to a strong fibrosis tissue formed by the periarticular soft tissues [1]. 


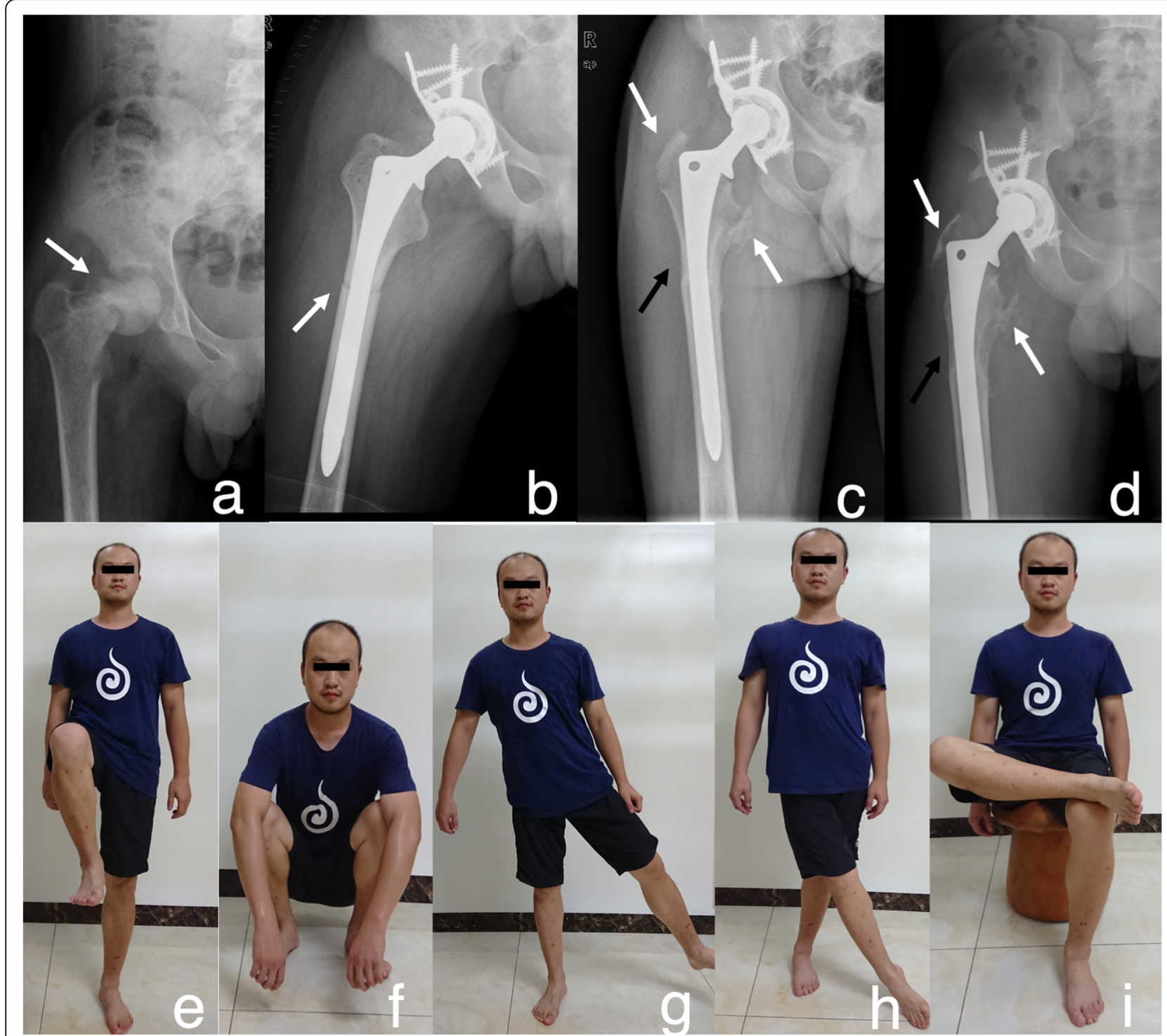

Fig. 1 Patient (No. 13) with the diagnosis of OS in the right femoral neck. a White arrow indicated pathological fracture occurred during the chemotherapy pre-operation. b The immediate radiograph after the reconstruction with uncemented APC. c-d 12 months and 96 months postoperation: white arrows indicated the avulsion of the trochanteric fractures, while the black arrow indicated the resorption of the allograft bone. e-i The function of the hip, 96 months post-operation

The bone union at the allograft-host junction seems regarded as one of the most important advantages of APC $[1,15,16]$. Theoretically, without the cement block at the allograft-host junction, the bone union could be achieved internally and externally [36]. Thus, from 2007, uncemented prosthesis was applied in our institute [23]. The results showed all patients achieved on-time bone union with the average union time of 7.6 months, which was shorter than most studies but comparable to Donati et al. and Malhotra et al. [13, 19-21, 30]. In addition, the nonunion rate at the allograft-host junction of our present study was much lower than previous studies including ours [20,21, 30, 32, 37]. This may be related to the granular allogenous bone grafting, the preservation of a $10-15 \mathrm{~mm}$ normal periosteal cuff, the initial stability between the stem and both the allograft and the host bone, and 4 weeks of bed rest after operation [23]. In our study, only 5 malignant patients received chemotherapy. Although chemotherapy could influence the union of the allograft-host junction, such a small proportion of chemotherapeutic patients in our series cannot confirm the relationship [38]. To minimize the nonunion rate at the allograft-host junction of cemented APC, short cemented stem with compressing plate has been introduced [18]. However, its own disadvantages cannot be avoided, such as extra destroying to the periosteum and related muscle 


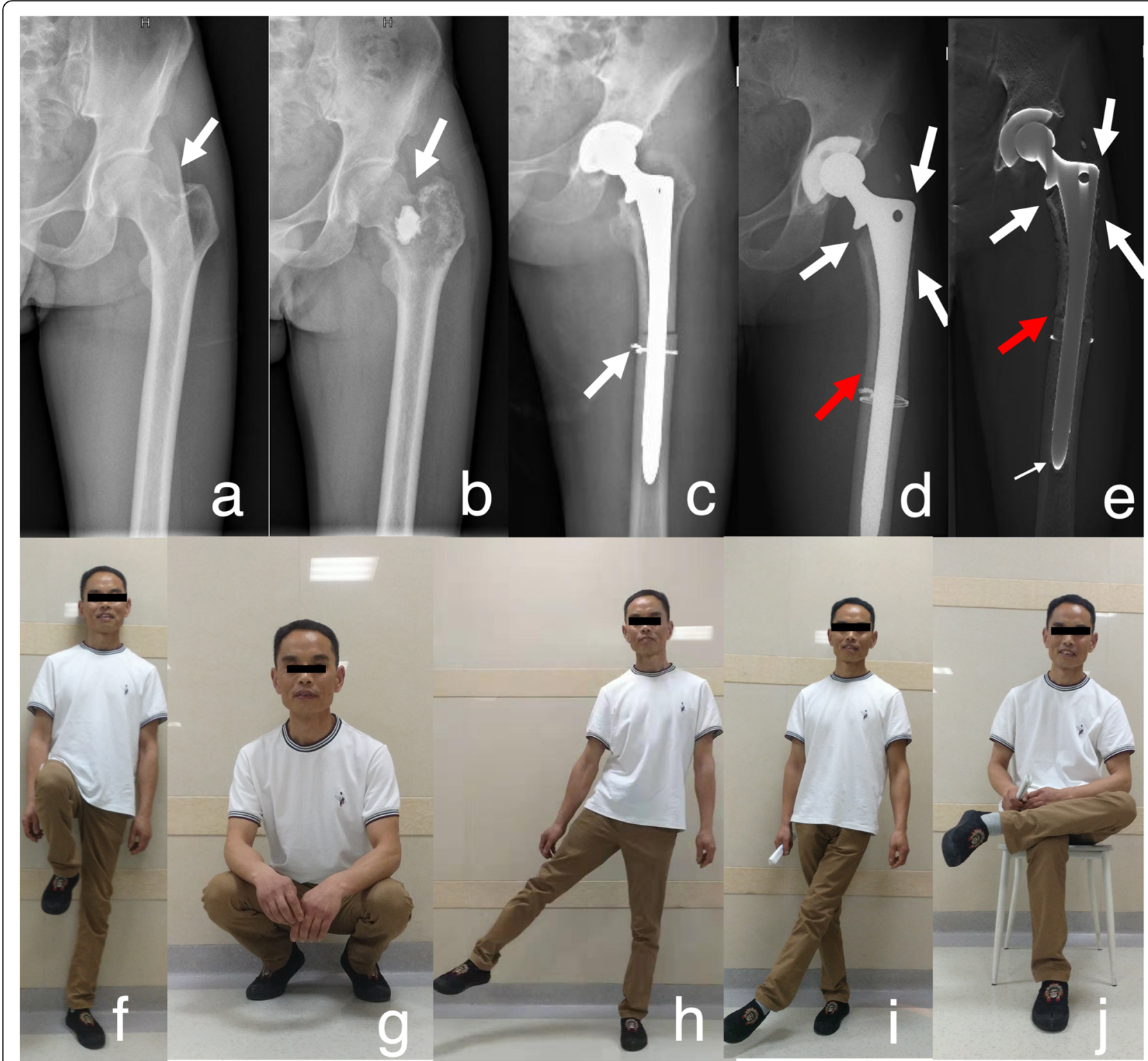

Fig. 2 Patient (No.10) with the diagnosis of OS of the left femoral neck. a The white arrow indicated the lesion. $\mathbf{b}$ The white arrow indicated the pathological fracture occurred after the incisional biopsy during chemotherapy. c Immediate radiograph after the surgery of uncemented APC, the white arrow expressed intraoperative fracture and fixed with cerclage wires. $\mathbf{d}$-e The last follow up radiograph and Tomosynthesis-Shimadzu metal artifact reduction technology (T-SMART) 107 months post-operation: the thick white arrows showed the resorption of the Gruen 1, Gruen2 and Gruen 7, the red arrows indicated bone union at the junction, the thin white arrows showed bone growing around the distal stem. (f-j) The function of the hip, 107 months post-operation

attachments, higher rate of PPPF, longer operative duration, longer incision and higher cost.

LR is another concern. The revision rate for tumor recurrence can be as high as $11 \%$ on endoprosthesis reconstruction, while $5 \%$ on APC $[15,39]$. One possible reason for lower recurrence on APC is the immunogenicity of damage-associated molecular patterns (DAMPs), which are triggers of allograft rejection following release from dying cells. These strong triggers of immune response will give rise to the success of cancer immunotherapy [40]. However, in our cohort, 3 patients (16.7\%) occurred LR, which was much higher than that of previous reports using endoprosthesis and APC reconstruction [9]. The potential reason is that among these 3 patients, 1 had previous surgery and pathological fracture while another 2 had a previous surgery before. This phenomenon has been discussed before [41].

The allograft resorption has been reported as high as $97.8 \%$ and usually occurred in Gruen zone 1 and 7 [1, $21,23]$, while one study also showed Gruen zone 2 and 
Table 3 Literature review of Allografts Prosthesis Composite for the tumoral skeletal defects in proximal femur

\begin{tabular}{|c|c|c|c|c|c|c|c|c|c|c|c|c|c|c|c|c|c|c|c|c|c|}
\hline \multirow[t]{2}{*}{ References } & \multirow[t]{2}{*}{ No } & \multicolumn{2}{|c|}{ Reasons } & \multirow{2}{*}{$\begin{array}{l}\text { Folllow- } \\
\text { up } \\
\text { (months) }\end{array}$} & \multicolumn{2}{|c|}{$\begin{array}{l}\text { Type of } \\
\text { Acetabulum }\end{array}$} & \multirow{2}{*}{$\begin{array}{l}\text { Union } \\
\text { time } \\
\text { (months) }\end{array}$} & \multicolumn{4}{|c|}{ Type of fixation } & \multirow[t]{2}{*}{$\begin{array}{l}\text { OR } \\
\text { (\%) }\end{array}$} & \multicolumn{6}{|c|}{ Complications } & \multirow[t]{2}{*}{$\begin{array}{l}\text { LS } \\
\text { (\%) }\end{array}$} & \multicolumn{2}{|c|}{ Assessment } \\
\hline & & $\mathrm{Tu}$ & RHA & & THA & $\mathrm{Bi}$ & & $\mathrm{CA}$ & UCA & PCA & AP & & $\mathrm{AL}$ & SF & IN & $\begin{array}{l}\text { TP/ } \\
\text { D }\end{array}$ & Non & Ins & & HHS & $\begin{array}{l}\text { MSTS } \\
(\%)\end{array}$ \\
\hline Gitelis [12] & 11 & 11 & / & / & / & / & / & 7 & I & 4 & 4 & I & / & / & I & I & / & / & / & / & I \\
\hline Zehr [13] & 18 & 18 & / & $\begin{array}{l}63,2(9- \\
122)\end{array}$ & 11 & 7 & $\begin{array}{l}13.5(12- \\
15)\end{array}$ & 14 & 2 & 2 & 2 & / & / & / & 3 & / & 1 & / & 94 & / & $\begin{array}{l}77.7 \\
(67-83)\end{array}$ \\
\hline $\begin{array}{l}\text { McGoveran } \\
{[11]}\end{array}$ & 16 & 16 & / & $\begin{array}{l}47(24- \\
93)\end{array}$ & / & / & / & 5 & / & 11 & 2 & 43.8 & / & 3 & 3 & / & 2 & / & 100 & / & 58.3 \\
\hline Donati [30] & 27 & 27 & / & $\begin{array}{l}58(11- \\
126)\end{array}$ & 3 & 24 & $7(3-12)$ & 4 & / & 23 & / & 18.2 & / & 1 & 1 & 5 & 1 & / & 100 & / & $\begin{array}{l}92(75- \\
100)\end{array}$ \\
\hline $\begin{array}{l}\text { Langlais } \\
{[15]}\end{array}$ & 21 & 21 & / & 72 & / & / & / & 21 & / & / & / & 38 & 4 & / & / & 10 & 4 & / & 100 & / & $\begin{array}{l}76.9 \\
(43-97)\end{array}$ \\
\hline Farid [31] & 20 & 20 & / & $\begin{array}{l}77.5(24- \\
335)\end{array}$ & / & / & / & 18 & / & 2 & / & 40 & / & / & 1 & 8 & 2 & 2 & 100 & / & 82 \\
\hline Lee [16] & 15 & 1 & 14 & $\begin{array}{l}50.4(24- \\
117.6)\end{array}$ & 15 & / & $\begin{array}{l}11.6(4- \\
16)\end{array}$ & 3 & / & 12 & / & 26.7 & 2 & / & 1 & / & 2 & 1 & / & $\begin{array}{l}83.2 \\
(67-96)\end{array}$ & / \\
\hline Biau [17] & 32 & 32 & / & $\begin{array}{l}68(2- \\
232)\end{array}$ & 22 & 10 & I & 32 & / & / & / & 28.1 & 1 & 3 & 4 & 1 & / & / & 100 & / & / \\
\hline $\begin{array}{l}\text { Muscolo } \\
{[18]}\end{array}$ & 38 & 26 & 12 & $\begin{array}{l}90(36- \\
204)\end{array}$ & 38 & / & / & / & / & 38 & 38 & 29 & I & 7 & 3 & 1 & / & / & 96 & / & $\begin{array}{l}90 \\
(43.3- \\
100)\end{array}$ \\
\hline $\begin{array}{l}\text { Malhotra } \\
\text { [19] }\end{array}$ & 18 & 18 & / & $\begin{array}{l}54(18- \\
79)\end{array}$ & 18 & / & $\begin{array}{l}6.8(4.5- \\
11)\end{array}$ & / & / & 18 & / & / & I & / & / & / & / & / & 100 & $\begin{array}{l}90.3 \\
(84-96)\end{array}$ & / \\
\hline Min [23] & 12 & 12 & / & $\begin{array}{l}24(16- \\
35)\end{array}$ & 7 & 5 & $(5-9)$ & / & 12 & / & / & / & I & / & / & / & / & / & 100 & $\begin{array}{l}81.6 \\
(66.2- \\
92.7)\end{array}$ & $\begin{array}{l}87.3 \\
(80- \\
96.7)\end{array}$ \\
\hline Min [20] & 28 & 28 & / & $\begin{array}{l}50.7(15- \\
138)\end{array}$ & 17 & 11 & $(9-18)$ & 28 & / & / & / & 3.6 & / & 2 & / & / & 6 & / & 100 & $\begin{array}{l}80.6 \\
(66.2- \\
92.7)\end{array}$ & $\begin{array}{l}88.3 \\
(70- \\
96.7)\end{array}$ \\
\hline Dubor y[1] & 46 & 32 & 14 & $\begin{array}{l}176.4 \\
(75.6- \\
391.2)\end{array}$ & 32 & 14 & / & 42 & 2 & 2 & / & / & 4 & 6 & 3 & 5 & 7 & 4 & / & / & $\begin{array}{l}77(50- \\
96.7)\end{array}$ \\
\hline $\begin{array}{l}\text { Current } \\
\text { series }\end{array}$ & 18 & 18 & / & $\begin{array}{l}106.7 \\
(65-141)\end{array}$ & 18 & / & $\begin{array}{l}7.6(5- \\
10)\end{array}$ & / & 18 & / & / & 22.2 & / & 2 & / & 3 & / & / & 94.4 & $\begin{array}{l}83(48- \\
100)\end{array}$ & $\begin{array}{l}80 \\
(33.3- \\
100)\end{array}$ \\
\hline
\end{tabular}

Abbreviations: No Number, Tu Tumor, RHA Revision of hip arthroplasty, THA Total hip arthroplasty, Bi Bipolar, CA Cemented allograft composite, UCA Uncemented allograft composite, $P C A$ Partial cemented allograft composite, AP Additional plate, OR Overall revision rate, AL Aseptic loosening, SF Structural failure, IN Infection, TP Tumor progressing, D Death, Non Non-union, Ins Instability, LS Limb Salvage, HHS Harries Hip Score, MSTS Musculoskeletal Tumor Society

3 were the most affected areas [29]. In our series, the Gruen zone 1 and 7 were the most ordinary and severe affected zones, of which half was combined with moderate resorption in the Gruen zone 2. Three reasons may lead to the high rate of the allograft resorption. First, the surrounding tissue of the allograft composes of chronic inflammatory cells, histiocytes and foreign-body giant cells, which will active osteoclastic resorption [36]. Second, Gruen 1 and Gruen 7 are known as the tensile stress zone. The stress centralized in these areas after iliopsoas and gluteus medius reattachment may cause the resorption [23]. Finally, the allograft remodeling consists of 3 consecutive phases, resorption, reversal and formation [42]. Interestingly, no statistical significance was observed with regard to function between patients who developed resorption or not $(P=0.082)$. From our viewpoints, the reason may be related to a strong fibrous tissue shaped by the periarticular soft tissues and inserted on the composite allograft [1]. No treatments were taken for these patients as there was no obvious radiolucent line between the allograft and the prosthesis, no subsidence of the prosthesis in the allograft and asymptomatic.

Our study has some limitations. On one hand, our study was limited with its retrospective design with no control group. On the other hand, the sample in this study was small. Although our study was the largest uncemented APC sample reconstruction for neoplastic defect of the proximal femur, only 18 patients with a minimal 65 months follow-up were included. A multicenter with more samples were needed. 


\section{Conclusion}

Uncemented APC holds the merits of shortening bone union time at the allograft-host junction and fewer nonunion. Based on our previous short-term outcome, longterm clinical results further verify that it is a reliable reconstruction. With proper procedures and postoperative management, patients can achieve good results in the long-term follow-up, particularly for those who were expected for long living with a good function after resection of the proximal femoral bone neoplasm. Although some complications still exist, the resorption and trochanteric fracture seem to have no effect on the stability of the composite and the function.

\section{Supplementary Information}

The online version contains supplementary material available at https://doi. org/10.1186/s12891-021-03991-6.

Additional file 1.

Additional file 2

\section{Abbreviations}

APC: Allograft prosthesis composite; RHA: Revision hip arthroplasty; CS: Chondrosarcoma; MFH: Malignant fibrous histiocytoma; GCTB: Giant cell tumor of bone; OB: Osteoblastoma; OBOS: Osteoblastic osteosarcoma; OS: Osteosarcoma; FBOS: Fibroblastic osteosarcoma; AJCC: American Joint Committee on Cancer; CT: Computed tomography; MRI: Magnetic resonance imaging; SPECT: Single-photon emission computed tomography; HHS: Harris Hip Score; MSTS: Musculoskeletal Tumor Society; AP: Anterior-posterior; TSMART: Tomosynthesis-Shimadzu metal artifact reduction technology; PPPF: Postoperative periprosthetic and prosthetic fracture; LR: Local recurrence; THA: Total hip arthroplasty; DAMPs: Damage-associated molecular patterns

\section{Acknowledgements}

We would like to thank the nurse team from the Department of Orthopedic Surgery, West China Hospital. We also would like to thank all the patients included in the current study.

\section{Authors' contributions}

All authors participated in the management of the patient in this case report. CL collected the data and drafted the manuscript. YZ, YL, FT and XZY collected and analyzed the data. LM designed, supervised the report and drafted the manuscript. MXL and WLZ prepared and revised of radiographs. $\mathrm{HD}$ and CQT critically revised the manuscript. All authors read and approved the manuscript.

\section{Funding}

This work was supported partially by three funders. The National Natural Science Foundation of China (no. 81801852) funded patient follow-up costs, Chengdu Science and Technology Project (no. 2017-CY02-00032-GX) funded data collection costs, and National Key Research and Development Program of China (no. 2016YFC1102003) funded the publication related fees.

\section{Availability of data and materials}

The datasets used and analyzed during the current study are available from the corresponding author on reasonable request.

\section{Ethics approval and consent to participate}

This study was approved and monitored by the Ethical Committee of West China Hospital, Sichuan University in China (No.2019228). All patients and (or) their guardians signed the informed consent.

\section{Consent for publication}

The written consent to publish images or other personal or clinical details of participants was obtained from the patients.

\section{Competing interests}

The authors declared no potential conflicts of interest with respect to the research, authorship, or publication of this study.

Received: 6 February 2020 Accepted: 19 January 2021

Published online: 01 February 2021

\section{References}

1. Dubory A, Mascard E, Dahan M, Anract P, Court C, Boisgard S, Viard B, Missenard G. Long-term functional and radiological outcomes of allograft hip prosthesis composite. A fourteen -year follow-up study. Int Orthop. 2017;41(7):1337-45.

2. Bus MPA, van de Sande MAJ, Taminiau AHM, Dijkstra PDS. Is there still a role for osteoarticular allograft reconstruction in musculoskeletal tumour surgery? A long-term follow-up study of 38 patients and systematic review of the literature. Bone Joint J. 2017:99-B(4):522-30.

3. de Santos LA, Murray JA, Parrish FF, Wallace S, Finkelstein B, Spjut HJ, Ayala AG, Terry AF. Radiographic aspects of massive bone osteoarticular allograft transplantation. Radiology. 1978;128(3):635-41.

4. Jofe MH, Gebhardt MC, Tomford WW, Mankin HJ. Reconstruction for defects of the proximal part of the femur using allograft arthroplasty. J Bone Joint Surg Am. 1988:70(4):507-16.

5. Rödl RW, Ozaki T, Hoffmann C, Böttner F, Lindner N, Winkelmann W Osteoarticular allograft in surgery for high-grade malignant tumours of bone. J Bone Joint Surg Br. 2000;82(7):1006-10.

6. Calori GM, Colombo M, Malagoli E, Mazzola S, Bucci M, Mazza E. Megaprosthesis in post-traumatic and periprosthetic large bone defects: issues to consider. Injury. 2014;45(Suppl 6):S105-10.

7. Benedetti MG, Bonatti E, Malfitano C, Donati D. Comparison of allograftprosthetic composite reconstruction and modular prosthetic replacement in proximal femur bone tumors: functional assessment by gait analysis in 20 patients. Acta Orthop. 2013;84(2):218-23.

8. Agarwal A, Larsen BT, Buadu LD, Dunn J, Crawford R, Daniel J, Bishop MC. Denosumab chemotherapy for recurrent giant-cell tumor of bone: a case report of neoadjuvant use enabling complete surgical resection. Case Rep Oncol Med. 2013;2013:496351.

9. Janssen SJ, Langerhuizen DWG, Schwab JH, Bramer JAM. Outcome after reconstruction of proximal femoral tumors: a systematic review. J Surg Oncol. 2019;119(1):120-9.

10. Xu G, Miwa S, Yamamoto N, Hayashi K, Takeuchi A, Igarashi K, Higuchi T, Taniguchi $Y$, Araki $Y$, Yonezawa $H$, et al. Pedicle frozen autograft-prosthesis composite reconstructions for malignant bone tumors of the proximal femur. BMC Musculoskelet Disord. 2020;21(1):81.

11. McGoveran BM, Davis AM, Gross AE, Bell RS. Evaluation of the allograftprosthesis composite technique for proximal femoral reconstruction after resection of a primary bone tumour. Can J Surg. 1999;42(1):37-45.

12. Gitelis S, Heligman D, Quill G, Piasecki P. The use of large allografts for tumor reconstruction and salvage of the failed total hip arthroplasty. Clin Orthop Relat Res. 1988;231:62-70.

13. Zehr R, Enneking WF, Scarborough MT. Allograft-prosthesis composite versus megaprosthesis in proximal femoral reconstruction. Clin Orthop Relat Res. 1996;322: 207-23.

14. Sternheim A, Drexler M, Kuzyk PR, Safir OA, Backstein DJ, Gross AE. Treatment of failed allograft prosthesis composites used for hip arthroplasty in the setting of severe proximal femoral bone defects. J Arthroplast. 2014:29(5):1058-62.

15. Langlais F, Lambotte JC, Collin P, Thomazeau H. Long-term results of allograft composite total hip prostheses for tumors. Clin Orthop Relat Res. 2003:414:197-211.

16. Lee SH, Noh SH, Chun KC, Han JK, Chun CH. A case of bilateral revision total knee arthroplasty using distal femoral allograft-prosthesis composite and 536 femoral head allografting at the tibial site with a varus-valgus constrained 537 prosthesis: ten-year follow up. BMC Musculoskelet Disord. 2018;19(1):69.

17. Biau DJ, Larousserie F, Thevenin F, Piperno-Neumann S, Anract P. Results of 32 allograft-prosthesis composite reconstructions of the proximal femur. Clin Orthop Relat Res. 2010;468(3):834-45.

18. Muscolo DL, Farfalli GL, Aponte-Tinao LA, Ayerza MA. Proximal femur allograftprosthesis with compression plates and a short stem. Clin Orthop Relat Res. 2010; 468(1):224-30. 
19. Malhotra R, Kiran Kumar GN, VKD, Kumar V. The clinical and radiological evaluation of the use of an allograft-prosthesis composite in the treatment of proximal femoral giant cell tumours. Bone Joint J. 2014;96-b(8):1106-10.

20. Min L, Tang F, Duan H, Zhou Y, Zhang WL, Shi R, Tu CQ. Cemented allograft-prosthesis composite reconstruction for the proximal femur tumor. Onco Targets Ther. 2015;8:2261-9.

21. Lee SH, Ahn YJ, Chung SJ, Kim BK, Hwang JH. The use of allograft prosthesis composite for extensive proximal femoral bone deficiencies: a 2- to 9.8-year follow-up study. J Arthroplast. 2009;24(8):1241-8.

22. Wilke BK, Houdek MT, Rose PS, Sim FH. Proximal femoral allograft-prosthetic composites: do they really restore bone? A retrospective review of revision allograftprosthetic composites. J Arthroplast. 2019;34(2):346-51.

23. Min L, Peng J, Duan H, Zhang W, Zhou Y, Tu C. Uncemented allograftprosthetic composite reconstruction of the proximal femur. Indian J Orthop. 2014;48(3):289-95.

24. Enneking WF: A system of staging musculoskeletal neoplasms. Clin Orthop Relat Res. 1986;(204)

25. Amin MB, Greene FL, Edge SB, Compton CC, Gershenwald JE, Brookland RK, Meyer L, Gress DM, Byrd DR, Winchester DP. The eighth edition AJCC Cancer staging manual: continuing to build a bridge from a population-based to a more "personalized" approach to cancer staging. CA Cancer J Clin. 2017;67(2):93-9.

26. Harris WH. Traumatic arthritis of the hip after dislocation and acetabular fractures treatment by mold arthroplasty. An end-result study using a new method of result evaluation. J Bone Joint Surg Am. 1969:51(4):737-55.

27. Enneking WF, Dunham W, Gebhardt MC, Malawar M, Pritchard DJ. A system for the functional evaluation of reconstructive procedures after surgical treatment of tumors of the musculoskeletal system. Clin Orthop Relat Res. 1993;286:241-6.

28. Gruen TA, McNeice GM, Amstutz HC. "Modes of failure" of cemented stem-type femoral components: a radiographic analysis of loosening. Clin Orthop Relat Res 1979:141:17-27.

29. Haddad FS, Garbuz DS, Masri BA, Duncan CP. Structural proximal femora allografts for failed total hip replacements: a minimum review of five years. J Bone Joint Surg Br. 2000;82(6):830-6.

30. Donati D, Giacomini S, Gozzi E, Mercuri M. Proximal femur reconstruction by an allograft prosthesis composite. Clin Orthop Relat Res. 2002;394:192-200.

31. Farid Y, Lin PP, Lewis VO, Yasko AW. Endoprosthetic and allograft-prosthetic composite reconstruction of the proximal femur for bone neoplasms. Clin Orthop Relat Res. 2006;442:223-9.

32. Babis GC, Sakellariou VI, O'Connor MI, Hanssen AD, Sim FH. Proximal femoral allograft-prosthesis composites in revision hip replacement: a 12-year follow-up study. J Bone Joint Surg Br. 2010;92(3):349-55.

33. Gitelis S, Piasecki P. Allograft prosthetic composite arthroplasty for osteosarcoma and other aggressive bone tumors. Clin Orthop Relat Res. 1991;270:197-201.

34. Aponte-Tinao LA, Ayerza MA, Muscolo DL, Farfalli GL. Should fractures in massive intercalary bone allografts of the lower limb be treated with ORIF or with a new allograft? Clin Orthop Relat Res. 2015;473(3):805-11.

35. Frisch NB, Charters MA, Sikora-Klak J, Banglmaier RF, Oravec DJ, Silverton CD. Intraoperative Periprosthetic femur fracture: a biomechanical analysis of Cerclage fixation. J Arthroplast. 2015;30(8):1449-57.

36. Enneking WF, Campanacci DA. Retrieved human allografts : a clinicopathological study. J Bone Joint Surg Am. 2001;83(7):971-86.

37. Chandler H, Clark J, Murphy S, McCarthy J, Penenberg B, Danylchuk K, Roehr B. Reconstruction of major segmental loss of the proximal femur in revision total hip arthroplasty. Clin Orthop Relat Res. 1994;298:67-74.

38. Hornicek FJ, Gebhardt MC, Tomford WW, Sorger Jl, Zavatta M, Menzner JP, Mankin $\mathrm{HJ}$. Factors affecting nonunion of the allograft-host junction. Clin Orthop Relat Res. 2001;382:87-98

39. Kabukcuoglu Y, Grimer R, Tillman RM, Carter SR. Endoprosthetic replacement for primary malignant tumors of the proximal femur. Clin Orthop Relat Res. 1999;(358).

40. Land WG, Agostinis P, Gasser S, Garg AD, Linkermann A. DAMP-induced allograft and tumor rejection: the circle is closing. Am J Transplant. 2016;16(12):3322-37.

41. Balke M, Ahrens H, Streitbuerger A, Koehler G, Winkelmann W, Gosheger G, Hardes J. Treatment options for recurrent giant cell tumors of bone. J Cancer Res Clin Oncol. 2009;135(1):149-58

42. Hadjidakis DJ, Androulakis II. Bone remodeling. Ann N Y Acad Sci. 2006; 1092:385-96.

\section{Publisher's Note}

Springer Nature remains neutral with regard to jurisdictional claims in published maps and institutional affiliations.

Ready to submit your research? Choose BMC and benefit from:

- fast, convenient online submission

- thorough peer review by experienced researchers in your field

- rapid publication on acceptance

- support for research data, including large and complex data types

- gold Open Access which fosters wider collaboration and increased citations

- maximum visibility for your research: over $100 \mathrm{M}$ website views per year

At $\mathrm{BMC}$, research is always in progress.

Learn more biomedcentral.com/submissions 